
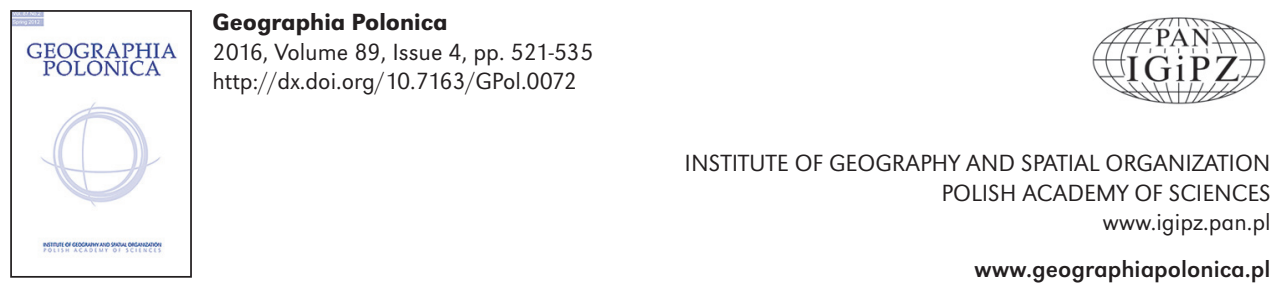

\title{
SHOPPING CENTRES AS THE SUBJECT OF POLISH GEOGRAPHICAL RESEARCH
}

\section{Agnieszka Rochmińska}

Faculty of Geographical Sciences

University of Łódź

Kopcińskiego 41, 90-142 Łódź: Poland

e-mail: agaroch@gmail.com

\begin{abstract}
This article seeks to present Polish achievements where research on the subject of shopping centres is concerned. The Polish research in this sphere is found to be both interdisciplinary and located within the sphere of interest of economists, sociologists, urban planners and geographers, among others. It is often therefore hard to determine which studies can be considered geographical. Are these ones dealt with by geographers, though often drawing upon the research of other academic disciplines? Or studies led by other researchers, but incorporating a geographical context? The subject of the development of modern commercial spaces (supermarkets, hypermarkets, discount stores, shopping centres, etc.) only appeared in the academic studies of Polish geography in the late 1990s, i.e. the time during which shops representing parts of foreign chain stores began to develop rapidly on the Polish market. In the Polish literature on shopping centres, the issues discussed most often concern the introduction of foreign investments into Poland, location (and relevant location factors), impacts on the functional and spatial structure of cities and urban renewal processes in what are mainly post-industrial areas, methods of spending free time, and the role and appropriation of public space. It is clear that the issue has not yet been exhausted, and that many challenges remain for the scientists, including geographers, who are willing to face them. One of the author's tasks is therefore to inspire and encourage geographers to explore further these new spaces that have appeared and are continuing to appear, not only within the functional and spatial structures of cities, but also in suburban areas.
\end{abstract}

\section{Key words}

shopping centre $\bullet$ geographical research on commerce $\bullet$ the influence of the shopping centre $\bullet$ hybrid space 


\section{Introduction}

The subject of the development of modern commercial spaces (supermarkets, hypermarkets, discount stores, shopping centres ${ }^{1}$, etc.) only appeared in Polish academic studies in geography in the late 1990s, when shops constituting parts of foreign chains began to develop rapidly on the Polish market. Furthermore, it remains the case that is single articles which appear, beyond individual researchers' main fields of scientific interest (i.e. as a marginal field of research).

Kaczmarek (2010) attempted to perceive these new commercial elements more generally - by reference to the strategies pursued in regard to the locating of shopping centres, while Rochmińska (2013) classified the centres present in large cities (drawing on the example of Łódź), as well as presenting spending and spatial behaviours, as these were seen to depend on types of offer and location.

The first attempt to identify the shopping centres present in Poland, whether operating already or still being built, was made by The Institute of the Domestic Market and Consumption (PI. Instytut Rynku Wewnętrznego i Konsumpcji, IRWiK) in 2000. At the mid-point of that year there were found to be some 140 multifunctional shopping centres either already in operation or being built; their combined floor-space area amounting to ca 1.7 $\mathrm{M} \mathrm{m}^{2}$ (Maleszyk 2000).

According to the calculations of KłosiewiczGórecka (2009) on the basis of the data from Pricewaterhouse Coopers and DTZ (Debenham Thouard Zadelhoff), Poland had 178 shopping

\footnotetext{
1 According to the definition (for statistical purposes), a shopping centre (S.C.) is a "commercial real estate that has been designed, built and managed as a single commercial entity, which consists of common elements, has a minimum gross leasable area (GLA) of five thousand square meters and contains at least 10 shops" (all quotations in this article are rendered by a translator). The definition of a shopping centre focuses particularly on the cohesive management of the complex, originality, the minimum leasable area and the existence of a common area for all clients with an appropriate number of service outlets; it should be mentioned that a suitably large parking area is also an important feature $(\mathrm{PRCH})$.
}

centres up and running by 2005 , the combined area by this point reaching almost $4 \mathrm{M} \mathrm{m}^{2}$. In turn the report (Raport - rynek powierzchni handlowych 2012) prepared by Cushman \& Wakefield states that, as of the end of 2011 Poland had no fewer than 387 functioning shopping centres, with a combined gross leasable area (GLA) of almost $7.7 \mathrm{M} \mathrm{m}^{2}$.

The PRCH Retail Research Forum calculated that, by 2015 , there were 455 complexes of the kind under consideration, while, according to Jones Lang Lasalle (JLL), the 2015 figure for floor space in modern commercial areas in Poland had reached $12.5 \mathrm{M} \mathrm{m}^{2}$, albeit with $71 \%$ of this in shopping centres per se, while $27 \%$ was in parks and large trading warehouses and $1 \%$ in outlet centres (JLL 2015).

Even on the basis of this not entirely comparable juxtaposition of data, it can be concluded that modern shopping centres influencing space and population behaviours have continued to be founded and developed in Poland, and are still being so.

Such constant and dynamic development of forms concentrating trade, services and entertainment has obviously raised new academic questions for researchers, and it is therefore the purpose of this article to present Polish achievements where shopping-centre research is concerned. At the outset, it should be noted that the issue is by no means exhausted yet, with many challenges still lying ahead of those scientists, including geographers, who are willing to take them up. One of the author's tasks is therefore to inspire and encourage geographers to further explore these new spaces that are continuing to appear, not only within the functional and spatial structures of cities, but also in suburban areas.

\section{Polish research on shopping centres}

Geographers' primary research interests as regards shopping centres relate to stages of development these new types of (or formats 
for $\left.{ }^{2}\right)$ commerce and services have passed through, as well as their distributions within given Polish cities, like Lublin, Wrocław, Łódź, Kraków, the Katowice agglomeration and Warsaw. Ciok and Ilnicki (2011) remark that the work of this kind has mainly sought to achieve 'registration'.

Attention should be paid to presentations of the development of large-format trade in Poznań (Kaczmarek 2010, 2011, among others) and in Wrocław (Ciok \& Innicki 2011), which has been achieved in the context of changes affecting all retail businesses in these cities. Alongside their studies of urban areas, geographers have also begun researching the introduction of foreign chain stores into both individual regions (like eastern Poland and Lower Silesia (Dolnośląkie Voivodeship) and the country as a whole (Tab. 1).

In turn, especially crucial and interesting issues relating to large-format trade complexes (mainly shopping centres) that the geographical sciences have researched involve the identification of the stages through which chain stores have made their appearance in various parts of Poland; as well as factors (general and detailed) underpinning or relating to the location of these, not least as regards:

- the rank of cities with chain stores through application of the concept of the net in service research (Wilk 2005),

- shopping centres as locations for leisure activities (Wilk 2003; Rochmińska 2011) and as new tourist attractions (Wilk 2003; Fuhrmann 2008; Dudek-Mańkowska \& Fuhrmann 2009),

- shopping centres as 'appropriated' public space (Janiszewska et al. 2011; Rochmińska 2014),

- the mechanics to the positive and negative influences large-format stores exert on their environment (Gwosdz \& Sobala-Gwosdz 2008; Sobala-Gwosdz \& Gwosdz

\footnotetext{
2 The notion of format refers to a specified manner, either stationary or non-stationary, in which retailing is managed (the term has been taken from English literature). Relevant literature treats it synonymously with the notion of type of shop or store (Borusiak 2008).
}

2011), e.g. on retail-outlet structure (Kaczmarek 2010, 2011; Ciok \& Ilnicki 2011),

- the orientation of trade in the urban renewal of post-industrial areas (Domański 2000, 2009; Jarczewski \& Huculak 2010),

- the influence of the trade function on functional and spatial structure (Werwicki 2000, 2001; Jarosz 2002; Kłosowski 2002; Heffner \& Twardzik 2013) (Tab. 1).

The geographical research on shopping centres should be approached with both a critical and a positive attitude. The problem facing city centres has been noted, and this has led to discussion-based research. Unfortunately, however, most of this revolves around the registration of dynamic change in the factual depiction of shopping-centre distribution, with determining factors mostly not sought.

Equally, the appearance of work pointing to the new roles shopping centres play as new tourist attractions, places to spend free time, and so on, combines with discussion regarding the 'public' nature of these places and research on general determinants underpinning their distribution, as well as location factors as such, to open up future possibilities for geographers to deal more fully with these modern trade and service spaces that not only change the image of cities, but also exert a transforming influence where people's movements are concerned.

Studies relating to shopping centres have proved to be interdisciplinary in nature. Beyond the geographical studies, mention is to be made of the work of economists whose research deals with relevant issues more often and in a more in-depth way (if usually from a different angle). The studies in question most often fall within the scope of research on trade, mainly retailing (Szulce 1998; Szumilak 2004; Sławińska 2008). In economic literature, these types of issues are especially examined as processes of concentration and integration in trade are introduced (Pokorska \& Maleszyk 2002, 2006; Maleszyk 2009, 2011; Domański 2006; Kucharska \& Twardzik 2007; Ciechomski 2006, 2010); as foreign investment in retailing is discussed, as the development of shopping centres 
Table 1. Shopping centres as the subject of Polish geographical research (key aspects)

\begin{tabular}{|c|c|}
\hline Subject of research & Study \\
\hline \multicolumn{2}{|c|}{ Development on the Polish market } \\
\hline $\begin{array}{l}\text { - the appearance of foreign chain stores in Poland, } \\
\text { its regions and cities } \\
\text { - the role of shopping centres in the process } \\
\text { of economic transformation }\end{array}$ & $\begin{array}{l}\text { Cities: Poznań (Kaczmarek 2010, 2011, among others); } \\
\text { Wrocław (Ciok \& Ilnicki 2011); Łódź (Rochmińska 2005, } \\
\text { 2013); Dzieciuchowicz (2012). } \\
\text { Regions: Eastern Poland (Gwosdz \& Sobala-Gwosdz } \\
\text { 2008; Sobala-Gwosdz \& Gwosdz 2011); Lower Silesia } \\
\text { (Dolnoślaskie Voivodeship) (Brezdeń \& Spallek 2010) } \\
\text { Country: (Taylor 2000; Wilk 2005; Kaczmarek 2010). }\end{array}$ \\
\hline $\begin{array}{l}\text { - location factors (general or detailed) } \\
\text { - distribution within regions or city structure }\end{array}$ & $\begin{array}{l}\text { Lublin (Kociuba 2006); Wrocław (Namyślak 2006); } \\
\text { Łódź(Rochmińska 2005, 2010, 2013); Kraków } \\
\text { (Więcław 2000, 2003); the Katowice agglomeration } \\
\text { (Kłosowski 2002); Warsaw (Fuhrmann 2007; } \\
\text { Dudek-Mańkowska \& Fuhrmann 2009). }\end{array}$ \\
\hline \multicolumn{2}{|c|}{ Offers and their attractiveness } \\
\hline $\begin{array}{l}\text { - offers and their attractiveness } \\
\text { - functions } \\
\text { - places to spend free time } \\
\text { - new tourist attractions }\end{array}$ & $\begin{array}{l}\text { Wilk (2003, 2004, 2005); Winiarczyk-Raźniak (2007); } \\
\text { Dudek-Mańkowska \& Fuhrmann (2009); Fuhrmann } \\
\text { (2008); Rochmińska (2011, 2013); Dzieciuchowicz } \\
\text { (2012). }\end{array}$ \\
\hline \multicolumn{2}{|c|}{ Influence on location and environment } \\
\hline $\begin{array}{l}\text { - on various levels: economic, social, cultural, } \\
\text { psychological, spatial, environmental }\end{array}$ & $\begin{array}{l}\text { Więcław (2000, 2003); Więcław-Michniewska (2006); } \\
\text { Gwosdz \& Sobala-Gwosdz (2008); Wójcik (2009); } \\
\text { Kaczmarek (2010, 2011); Ciok \& Ilnicki (2011); } \\
\text { Sobala-Gwosdz \& Gwosdz (2011). }\end{array}$ \\
\hline \multicolumn{2}{|c|}{ Role and function in city structure } \\
\hline $\begin{array}{l}\text { - the relationship with city centres } \\
\text { - the position in the structure of public space } \\
\text { - S.C. - as a product } \\
\text { - the influence on the functional and spatial } \\
\text { structure of a city } \\
\text { - trade orientation in urban renewal }\end{array}$ & $\begin{array}{l}\text { Werwicki (2000, 2001); Jarosz (2002); Kłosowski } \\
\text { (2002); Domański (2000, 2009); Ledwoń (2009); } \\
\text { Jarczewski \& Huculak (2010); Janiszewska et al. (2011); } \\
\text { Knecht-Tarczewska (2011); Kaczmarek (2012); Heffner } \\
\text { \& Twardzik (2013); Rochmińska (2013, 2014). }\end{array}$ \\
\hline \multicolumn{2}{|c|}{ Clients } \\
\hline $\begin{array}{l}\text { - client profiles } \\
\text { - spending behaviour } \\
\text { - spatial behaviour }\end{array}$ & $\begin{array}{l}\text { Kłosowski (2002); Winiarczyk-Raźniak (2007); } \\
\text { Rochmińska (2011, 2013). }\end{array}$ \\
\hline
\end{tabular}

is presented (Maleszyk 1998, 1999, 2001, 2004), and as marketing strategies for the development of large shopping centres are introduced (Domański 2001; Pilarczyk et al. 2001; Domański 2005). The role of local government in the development of trade, including large-area commerce, as well as the latter's influence on local and regional development are inter alia discussed in Kłosiewicz-Górecka \& Słomińska (2001), Kłosiewicz-Górecka (2006) and Mikołajczyk (2008).

Studies by economists inter alia allow for a fuller acquaintanceship with the development of this kind of retailing around the world, including in Europe, the stages via which and rate at which foreign shopping centres entered on to the Polish market, the location strategies pursued by individual companies, and the influence of commercial complexes on the development of Poland, its separate regions and individual localities (be these gminas or cities).

While the work done by geographers and economists proves highly useful for theoretical debates, it remains insufficient in many aspects, making it worthwhile for those interested to familiarise themselves with further work 
in the fields of sociology (e.g. Makowski 2003; Jałowiecki 2011) and geomarketing - i.e. the combination of the science of trade with transport (e.g. Fularz 2004; Zipser 2006), etc.

\section{Selected research aspects}

\section{Research on the influence shopping centres exert}

In Poland, studies are being conducted regarding the positive and negative influences on their environment of large-format commercial complexes. However, these are too often focused on selected aspects. Nevertheless worth mentioning here are the studies on the influence of large-format shops on the structure of commercial outlets, (e.g. Kłosowski 2002; Kaczmarek 2010, 2011; Ciok \& Innicki 2011), on the discharge of selected tasks by local authorities (Więcław 2000, 2003; Więcław-Machniewska 2006), on the local economy (Gwosdz \& Sobala-Gwosdz 2008; Sobala-Gwosdz \& Gwosdz 2011), on functional changes in the areas in which shopping centres are located (Namyślak 2006), on public space (Fuhrmann 2006;
Celińska-Janowicz 2011; Janiszewska et al. 2011; Rochmińska 2014), on society (Wójcik 2009; Rochmińska 2011; Heffner \& Twardzik 2013), on quality of life (Fuhrmann 2007), on attractiveness of cities, including attractiveness to tourists (Kociuba 2006; Fuhrmann 2008; Siemieniako 2009; Kochaniec 2011; Budner 2011; Dzieciuchowicz 2012), on the capacity to fulfil human needs (Dębek 2014), on the sense of safety in shopping centres (Mordwa 2012), and so on.

Even the smallest complexes are large enough to create areas of influence, and to shape urban or even non-urban areas. The range, power and type of influence a shopping centre exerts on its environment is dependent on characteristics such as location, accessibility, time of opening, size, type and type of offer (Fig. 1). None of these features can be assessed separately, and many are interreliant. Indeed, it is sometimes only as a group that can influence the type of changes ongoing in shopping centre locations and environments. Furthermore, this influence can exert its effect on both the material (physical) and non-material (social and psychological) levels.
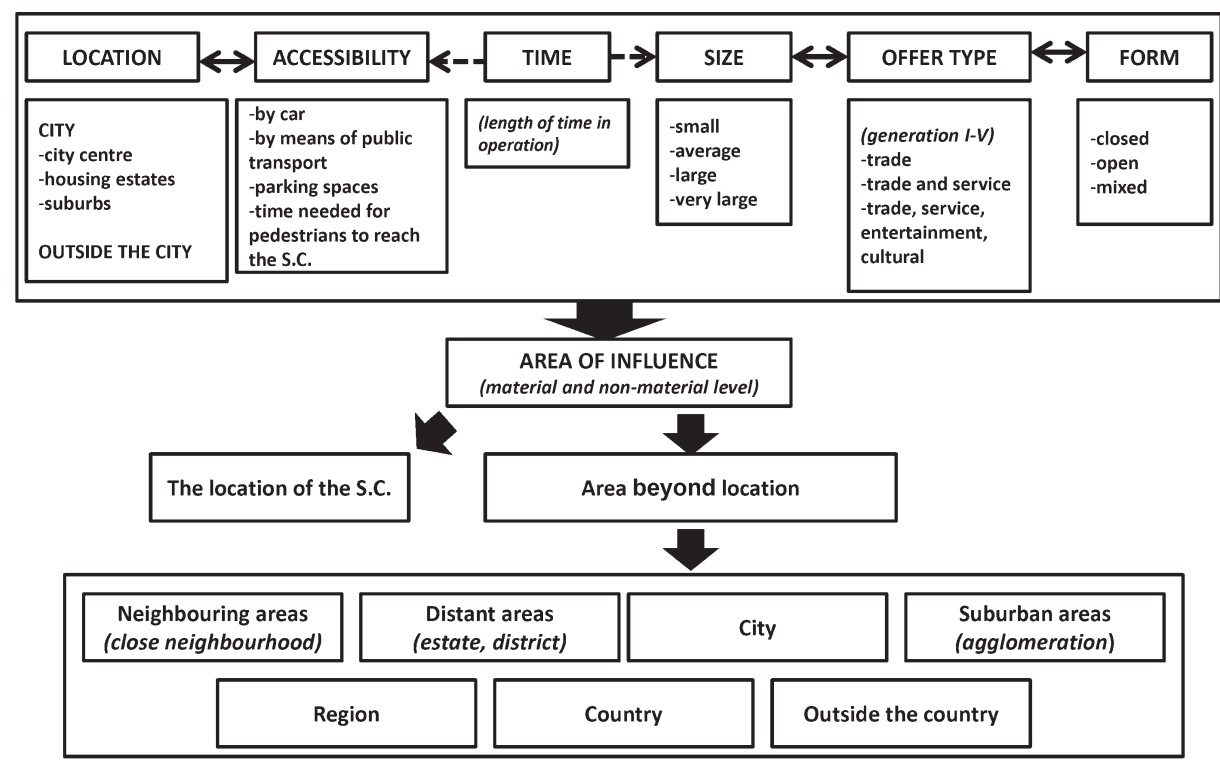

Figure 1. The features of shopping centres determining the power, type and size of the area of influence Source: Rochmińska 2015. 
The research conducted in various Polish cities (e.g. Więcław 2000; Kociuba 2006; Namyślak 2006; Rochmińska 2005, 2013 and Kaczmarek 2011) shows that modern commercial complexes are found mainly in warehouse locations and on industrial wasteland (due to the low costs of purchasing land for new development, and a desire to dispose of useless areas on the part of unprofitable production plants). Factors of importance in the selection of locations also include accessibility by means of transport, location by city exit roads (attracting customers from outside the city) and the immediate proximity of a ready market - close to large housing estates or the city centre (densely populated).

The development of a shopping centre in a given area usually has functional changes associated with it, e.g. with industrial or agricultural areas becoming commercial or service-related areas. In line with the previous functions of the area in which commercial or service-related buildings are now located, the area can be considered a greenfield (in agricultural areas), a brownfield (in industrial wasteland), or a location with other commercial properties. However, the location of the shopping centre need not always denote functional change, as where a new shopping centre is erected in an area previously accommodating a similar complex (location on greyfield areas ${ }^{3}$ ) which either lost its attractiveness or went bankrupt and was closed ${ }^{4}$. The fact that such new developments change the image of a location area, becoming competitive with other city areas, including city centres, needs to be taken into consideration.

Shopping centres influence, not only their own location but also its environment. In the case of the large or even extremely large

${ }^{3}$ Greyfield - trade properties that require a public or private intervention to prevent their collapse. Greyfields are developed areas, prepared economically and physically for major redevelopment (A study by Congress 2001).

4 These types of transformation take place, inter alia, in the USA, e.g. with the transformation of the closed Plaza Pasadena shopping centre with an open structure, modelled after the traditional layout of the city, located in Paseo Colorado. complexes that constitute a concentration of many service outlets (mainly commercial), and often also cultural or entertainment establishments, their influence on the surrounding area and people is significant and leaves its mark at both a material and a non-material level. Moreover, these changes can be either positive - benefitting, or negative - causing great disadvantages for - both local development and local people.

Thus the results of the operations of these modern trade and service complexes may appear on different levels, and should therefore be analysed from a multi-dimensional perspective, via a holistic approach. The economic, social, cultural, psychological, spatial (including infrastructural) and environmental levels need to be taken into consideration (Fig. 2).

The influence on the environment is also observed by the customers of such commercial and service-related complexes. In 2011, customers at shopping centres in Łódź were asked to give arguments 'for' and 'against' the creation of such complexes in the immediate vicinity of their homes. Most spoke against the building of such a complex 'right by their windows', fearing increased traffic, a negative influence on the natural enironment and landscape aesthetics, and a reduced feeling of safety. In turn, those respondents that would have liked such a complex close to their homes argued for the time- and money-saving aspects, as well as the independence of means of transport (Tab. 2).

The research shows that a majority of respondents note the potential negative effects of a shopping centre being built close to their homes. It needs to be emphasized that many of those surveyed assessed the location thereof, not only as potentially beneficial, but also in a wider context. The fears expressed by the customers of shopping centres in Łódź, in relation to a hypothetical location close to their own homes, reflect an awareness of a negative influence on the quality of life. On the one hand, such a phenomenon can result from empirical experience, while on the other it can stem from a perspective on the subject, a conception or knowledge. 


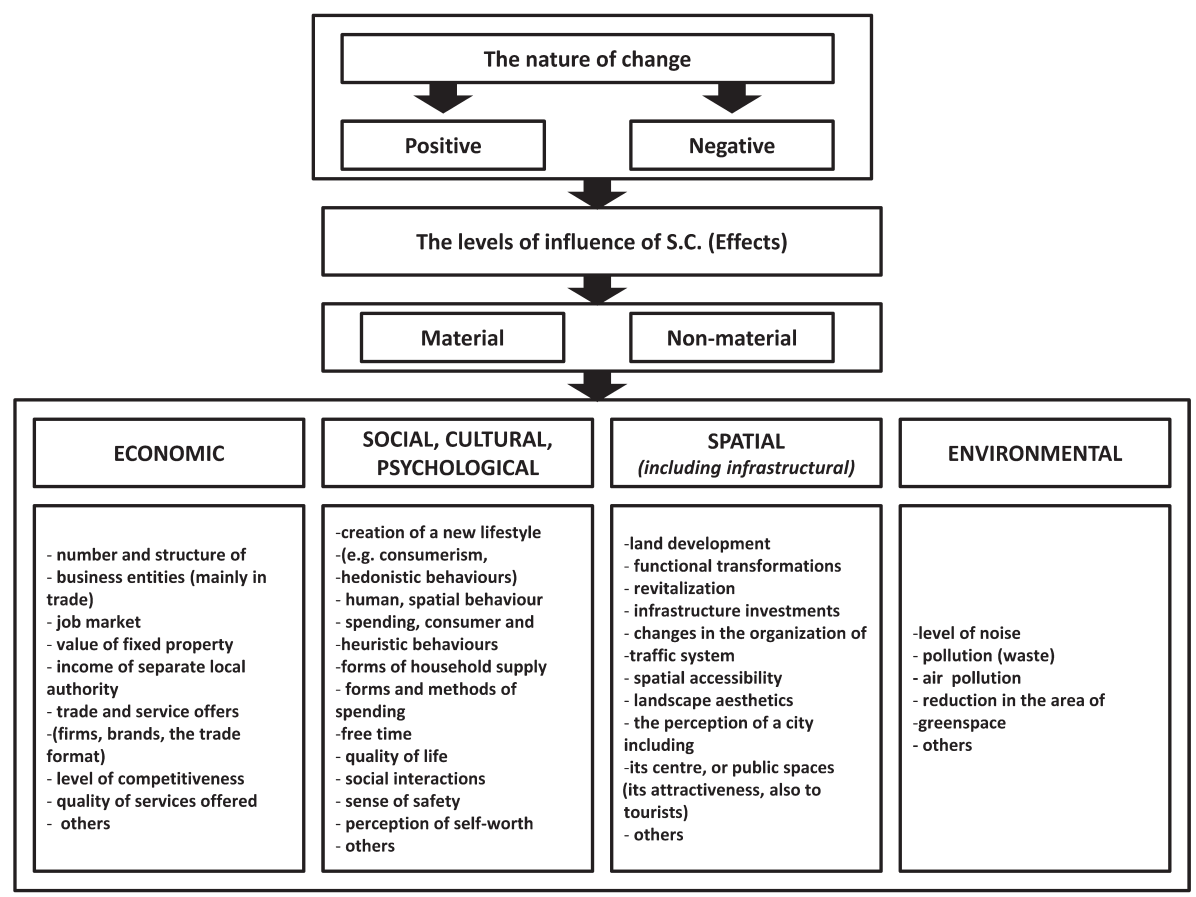

Figure 2. Levels of influence exerted by shopping centres

Source: Rochmińska 2015.

Table 2. The most common arguments 'against' and 'for' the founding of a shopping centre in the immediate vicinity of a respondent's home [ $\mathrm{N}=2420]$

\begin{tabular}{|c|c|c|c|}
\hline No. & Categories & Arguments & $\begin{array}{l}\text { Number } \\
\text { of indications }\end{array}$ \\
\hline \multicolumn{4}{|c|}{ Arguments 'against' } \\
\hline 1. & $\begin{array}{l}\text { Pedestrian/road } \\
\text { traffic }\end{array}$ & $\begin{array}{l}\text { - transport problems (increased road traffic - traffic jams, noise, } \\
\text { exhaust fumes, filling of parking spaces, destruction of roads), } \\
\text { - event organization - noise, commotion, crowds, etc., }\end{array}$ & 1503 \\
\hline 2. & $\begin{array}{l}\text { Natural } \\
\text { environment }\end{array}$ & $\begin{array}{l}\text { - air pollution, } \\
\text { - destruction of greenery, } \\
\text { - appearance of illegal rubbish dumps, }\end{array}$ & 85 \\
\hline 3. & $\begin{array}{l}\text { Landscape } \\
\text { aesthetics }\end{array}$ & $\begin{array}{l}\text { - blotting and obscuring the landscape, dazzling neon lights } \\
\text { - the need for a nice view "out the window" }\end{array}$ & 76 \\
\hline 4. & Sense of safety & $\begin{array}{l}\text { - increased crime, e.g. thefts, scuffles, } \\
\text { - the appearance of the homeless, beggars, inebriated people, } \\
\text { - road traffic risks }\end{array}$ & 34 \\
\hline 5. & Time and money & $\begin{array}{l}\text { - more time spent on shopping, } \\
\text { - the temptation of unnecessary shopping, } \\
\text { - increased expenditure }\end{array}$ & 15 \\
\hline 6. & $\begin{array}{l}\text { Community } \\
\text { stores }\end{array}$ & $\begin{array}{l}\text { - competitiveness in terms of costs and assortment, } \\
\text { - capability of causing bankruptcies }\end{array}$ & 15 \\
\hline 7. & Other & $\begin{array}{l}\text { - excessive number in the city already } \\
\text { - reduced fixed property prices }\end{array}$ & 147 \\
\hline
\end{tabular}




\begin{tabular}{|c|c|c|c|}
\hline No. & Categories & Arguments & $\begin{array}{l}\text { Number } \\
\text { of indications }\end{array}$ \\
\hline \multicolumn{4}{|c|}{ Arguments 'for' } \\
\hline 1. & Distance & $\begin{array}{l}\text { - proximity of shops, } \\
\text { - money-saving (e.g. cheap products, sales), } \\
\text { - comfort (e.g. for elderly or disabled people) }\end{array}$ & 284 \\
\hline 2. & Time & $\begin{array}{l}\text { - time-saving, } \\
\text { - the possibility of shopping anytime }\end{array}$ & 118 \\
\hline 3. & $\begin{array}{l}\text { Means } \\
\text { of transport }\end{array}$ & $\begin{array}{l}\text { - independence from means of transport, } \\
\text { - money-saving (no fuel costs) }\end{array}$ & 49 \\
\hline 4. & Other & $\begin{array}{l}\text { - potential place of employment, } \\
\text { - increased value of fixed property, } \\
\text { - better transport (new roads, more frequent bus runs, etc.), } \\
\text { - increased prestige of the neighbourhood or housing estate, } \\
\text { - more possible ways of spending free time }\end{array}$ & 17 \\
\hline
\end{tabular}

Source: Personal elaboration on the basis of questionnaire surveys (Rochmińska 2013) - as modified.

\section{Shopping centres in relation to public space}

The literature does not take a definite and clear-cut stand on the labelling of commercial complexes - it is not stated explicitly whether they should be considered public or private space, or a form altogether separate - a third type of so-called hybrid space. The discussion on classification is ongoing, and especially the debating as to classification in relation to the established definitions of public space. The source literature describes shopping centres as "private spaces accessible to the public" (Chmielewski 2004), "private spaces used by the public" (Hopkins 1991), "private public spaces" (Racoń-Leja 2007), "private consumerist spaces" (Bauman 2000), "substitutes for public space (...), which are not public spaces, but private areas used by the public" (Ghirardo 1999), "hermetic atria that attempt to imitate open public spaces", "public spaces isolated from the outside" (Racoń-Leja 2007), "quasi-public spaces" (Pancewicz 2010; Tyndall 2010), and "public-private hybrids" (Kohn 2004).

This short review of shopping centre labels indicates that they are rarely treated as purely public spaces, but instead - as areas in which "the appropriation of public spaces (...), the commercialization of space" (Mironowicz
2010) or "the functional usurpation with the private investors appropriating public spaces" (Kwiatkowski 2010) has taken place.

Public spaces, understood as areas with limitless access for everyone and allowing for freedom of behaviour and speech, have always been a crucial element of every city. Shopping centres are included in the city space, frequently becoming landmarks therein and competing with traditional public spaces. They are suitable public spaces in terms of quality, but, at the same time, they have many characteristics excluding them from this group.

In the public-private continuum, they constitute the in-between spaces - hybrid ones with the qualities of a suitable public space. Therefore, shopping centres are places concentrating numerous important social functions, replacing the traditional public spaces, including city centres. However, the public nature of these modern complexes is limited on many levels (as regards time, offer, personal issues, and behavioural restrictions - e.g. of a social or political nature). This makes it hard to treat shopping centres as public areas in the true sense. In line with the role of these modern trade and service spaces, positioning in relation to urban public spaces is a key matter. Certain relations between the traditional public spaces and hybrid spaces (including shopping centres) should be developed, in order 
that a city's inhabitants may benefit, while city functioning is improved (Rochmińska 2014).

\section{Shopping centre as a product}

Modern shopping centres are a commercial product with a varied offer that seeks to attract the greatest number of customers - who purchase items and leave behind as much money as possible. Due to that, the aim of both the managers and the subtenants of such complexes is to make buyers interested in what they have on offer. This becomes harder and harder with the building of evermore new shopping centres, due to the rising competition. The preparation of such a selection of offers that stand out against other complexes functioning on a given 'consumer' market is not easy. However, the (material and non-material) advantages, development and accessibility by means of transport help signify the attractiveness of each shopping centre (Rochmińska 2013).

Knecht-Tarczewska (2011) has determined the components of the product, based on the example of a shopping centre, and drawing a distinction between three levels of the core of the product, the product proper and the extended product. The core of the product that is the shopping centre comprises its offer, on both the material and non-material levels. Additional value is shaped by the product proper, which consists of: an advantageous location, architecture, mood, a sense of safety, the brand of the complex and the price range. The third level of advantages additional from the point of view of the buyer comprises the extended product, formed by customer loyalty programmes, events, social campaigns and the cultural programme.

As the notion of the shopping centre as a product is investigated, the located in a certain functional space affected to a greater or lesser degree cannot be forgotten. Mention has already been made of the way in which the building of a complex changes its location, not only in terms of functionality, but also visually. By influencing their environments, shopping centres shape a transformed and constantly changing urban space. The core (pole or heart) of the product of such a space consists of the shopping centre itself, understood

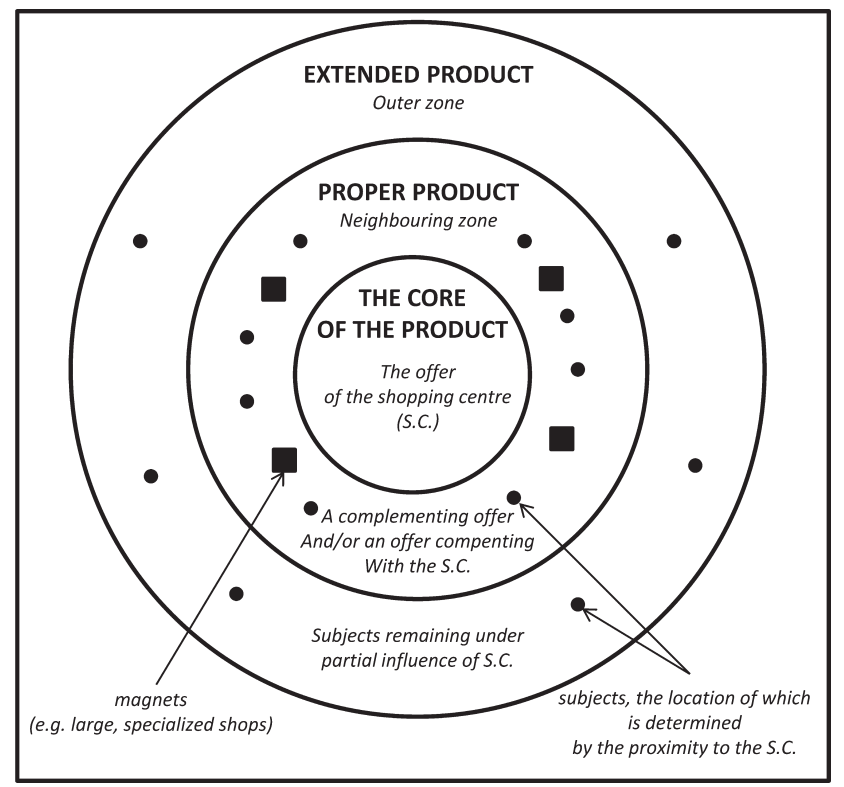

Figure 3. The offer of modern vibrant urban service levels

Source: Rochmińska 2013: 66. 
as a multidimensional offer product. However, in the vicinity of the centre, other trade outlets can appear as 'attachments' - often constituting large stores or specialised centres, e.g. Obi, Castorama or Praktiker. These types of facility increase the attractiveness of a given area, helping make up their so-called product proper. In some cases, other service outlets may also appear in the non-immediate vicinity, yet still with locations relating to the centre. These make up the extended product of the area (Fig. 3).

These large-format complexes are the vibrant urban cores of modern service space. They are the ones to generate streams of buyers, who may also be customers of neighbouring outlets, therefore influencing the attractiveness of the location of the whole area surrounding the shopping centre. Researching shopping centres as a product may thus lead to a better and fuller understanding and defining of the influence of a shopping centre on its environment, among other things.

\section{Conclusions}

The research on and into shopping centres is both interdisciplinary and placed within the circle of interest of economists, sociologists, urban planners and geographers, among others. Frequently, it is hard to determine which of the studies can be considered geographical. Are these the ones dealt with by the geographers, which often draw upon the research of other academic disciplines; or the ones lead by other researchers, but incorporating geographical context? The review of Polish geographical research detailed here makes it clear that work is mostly factual in nature, focused on the development, locations and distribution of shopping centres. This lack of a holistic approach is especially visible in research on the influence shopping centres exert on their environment.

Researchers should pay more attention to the influence of shopping centres in their immediate vicinity, for example in functional, social or landscape terms, or in relation to the structure of business (mainly service-related) entities, e.g. as regards the appearance, liquidation and relocation of facilities. Therefore, the more in-depth studies of the product of the vibrant cores of modern service and trade space and determining the range of their so-called trade areas (outlining the methods of determination), their segmentation and the identification of the factors and barriers determining the range of influence, also seem significant. These types of studies will help understand and predict the changes in customer migration and prevent the issues that arise as a consequence.

The above deliberations show that the topic of shopping centres has not yet been exhausted, with many challenges still facing researchers, geographers included. One of the author's tasks is to encourage and inspire geographers to further research these new spaces which have appeared and are still appearing in functional and spatial structures, mainly in cities, but also in suburban areas. The geographical field of research on modern trade and service complexes can still be extended to new areas of research. This is especially because the few existing studies are mostly meant as recording only. What is particularly important is the undertaking of methodological and theoretical studies. Some of the Polish research trends could be inspired by foreign studies, especially in countries where shopping centres have been functioning for a long time - i.e. American and (Western) European work in particular. Lately, shopping centres in other parts of the world have been undergoing dynamic and large-scale development prompting further academic study. Special attention should, for example, be paid to the interesting and innovative Chinese studies in this sphere.

Editors' note:

Unless otherwise stated, the sources of tables and figures are the authors', on the basis of their own research. 


\section{References}

A STUDY By CONGRESS, 2001. Greyfields into goldfields. From failing shopping centers to great neighbourhoods. Congress for the New Urbanism, San Francisco: PricewaterhouseCoopers, http://www.usmayors.org/brownfields/library/ greyfieldstogoldfields.pdf [15 June 2015].

Bauman Z., 2000. Globalizacja. Warszawa: Państwowy Instytut Wydawniczy.

BorUsIAK B., 2008. Modele wzrostu przedsiębiorstw handlu detalicznego. Poznań: Akademia Ekonomiczna.

Brezdeń P., Spallek W., 2010. Przestrzenne zróżnicowanie wielkopowierzchniowych sieci handlowych w województwie dolnoślqaskim i jego uwarunkowania [in:] Z. Zioło, T. Rachwał (eds.), Przedsiębiorczość w warunkach integracji europejskiej, Przedsiębiorczość - Edukacja, 6, Kraków: Nowa Era, Zakład Przedsiębiorczości i Gospodarki Przestrzennej Instytutu Geografii Uniwersytetu Pedagogicznego, pp. 294-307.

BUDNER W., 2011. Skutki oddziaływania sklepów wielkopowierzchniowych na istniejaca sieć handlowa i rynek pracy w Lesznie. Zeszyty Naukowe, no. 22, Poznań: Wyższa Szkoła Handlu i Usług, pp. 43-57.

Celińska-Janowicz D., 2011. Centra handlowe wobec miejskiej przestrzeni publicznej - nie tylko imitacja [in:] I. Jażdżewska (ed.), Człowiek w przestrzeni publicznej miasta. XXIV Konwersatorium Wiedzy o Mieście, Łódź: Uniwersytet Łódzki, pp. 149-156.

CHMIELEWSKI J.M., 2004. Rola miejskich przestrzeni publicznych. Urbanista, 4, pp. 23-41.

Ciechomski W., 2006. Koncentracja w handlu detalicznym - przesłanki, miary i skutki [in:] J. Mikołajczyk (ed.), Handel: Znaczenie we współczesnej gospodarce. Poznań: Wyższa Szkoła Handlu i Usług, pp. 89-99.

CieCHOMSKI W., 2010. Koncentracja handlu w Polsce $i$ jej implikacje dla strategii konkurowania przedsiębiorstw handlowych. Poznań: Uniwersytet Ekonomiczny.

CIOK S., ILNICKI D., 2011. Handel detaliczny w przestrzeni dużego miasta na przykładzie Wrocławia [in:] K. Marciniak, K. Sikora, D. Sokołowski (eds.), Koncepcje i Problemy Badawcze Geografii, Bydgoszcz: Wyższa Szkoła Gospodarki, pp. 219-237.

DęвеK M., 2014. Handel w przestrzeni zurbanizowanej - zarys form i ich funkcji z perspektywy ludzkich potrzeb [in:] R. Masztalski (ed.), Współczesne funkcje handlowe wybranych małych miast województwa dolnośląskiego, Wrocław: Oficyna Wydawnicza Politechniki Wrocławskiej, pp. 63-82.

Domański B., 2000. Restrukturyzacja terenów poprzemysłowych w miastach [in:] Z. Ziobrowski, D. Ptaszycka-Jackowska, A. Rębowska, A. Geissler (eds.), Rewitalizacja, rehabilitacja i restrukturyzacja - odnowa miast, Kraków: Instytut Gospodarki Przestrzennej i Komunalnej, pp. 107-142.

Domański B., 2009. Rewitalizacja terenów poprzemysłowych [in:] W. Jarczewski (ed.), Przestrzenne aspekty rewitalizacji: Śródmieścia, blokowiska, tereny poprzemysłowe, pokolejowe i powojskowe, Rewitalizacja miast polskich, 4, Kraków: Instytut Rozwoju Miast, pp. 125-138.

DomańSKI T., 2001. Strategie marketingowe dużych sieci handlowych. Warszawa: Państwowe Wydawnictwo Naukowe.

Domański T., 2005. Strategie rozwoju handlu. Warszawa: Polskie Wydawnictwo Ekonomiczne.

Domański T., 2006. Proces internacjonalizacji polskiego handlu. Wyzwania i zagrożenia dla polskich firm [in:] J. Mikołajczyk (ed.), Handel: Znaczenie we współczesnej gospodarce, Poznań: Wyższa Szkoła Handlu i Usług, pp. 29-36.

Dudek-Mańkowska S., Fuhrmann M., 2009. Centra handlowe trzeciej generacji w Warszawie, jako nowe produkty turystyczne [in:] A. Stasiak (ed.), Kultura i Turystyka - wspólnie zyskać, Łódź: Wyższa Szkoła Turystyki i Hotelarstwa, pp. 269-282.

DzIECIUCHOWICZ J., 2012. Wielkie centrum handlowe w przestrzeni miejskiej i podmiejskiej. Manufaktura w Łodzi i Ptak w Rzgowie. Łódź: Uniwersytet Łódzki.

FunRmann M., 2006. Miasto w mieście - przestrzeń centrum handlowego, jako substytut przestrzeni miejskiej [in:] Dynamika przestrzeni miejskiej, Poznań: Wydawnictwo Poznańskie, pp. 71-76.

Funrmann M., 2007. Centrum handlowe a jakość życia. Genius Loci, http://www.regioportal.pl/ pl28/teksty471/centrum_handlowe_a_jakosc_ zycia [12 May 2016].

FuHRMANN M., 2008. Znaczenie turystyczne centrów handlowych nowej generacji w Warszawie [in:] A. Stasiak (ed.), Turystyka i Hotelarstwo, 14, Łódź: Wyższa Szkoła Turystyki i Hotelarstwa, pp. 135-144. 
Fularz A., 2004. Rozwój podmiejskich centrów dystrybucji detalicznej w ujęciu ekonomiki transportu, Studia Regionalne i Lokalne, no. 4, pp. 145-158.

GHIRARDO D., 1999. Architektura po modernizmie. Toruń: VIA.

Gwosdz K., Sobala-Gwosdz A., 2008. Geografia hipermarketów w Polsce: Strategie lokalizacyjne firm i ich skutki przestrzenne. Przegląd Geograficzny, vol. 80, no. 4, pp. 515-539.

Heffner K., TwardziK M., 2013. Społeczne oddziatywanie nowoczesnych centrów handlowo-usługowych na małe miasta w zewnętrznej strefie aglomeracji ślq̨skiej [in:] K. Heffner, M.Twardzik (eds.) Ewolucja funkcji małych miast w Polsce, Studia Ekonomiczne. Zeszyty Naukowe Wydziałowe, 144, Katowice: Uniwersytet Ekonomiczny, pp. 95-109.

HopkIns J.S. P., 1991. West Edmonton Mall as a centre for social interactions, The Canadian Geographer, vol. 35, no. 3, pp. 268-279.

JAŁOWIECKI B., 2011. Studia miejskie - między historiq a teoria, Studia Regionalne i Lokalne, no. 2 (44), pp. 26-40.

Janiszewska A., Klima E., RochmińsKA A., 2011. Centra handlowe $w$ Łodzi - zawłaszczona, przestrzeń publiczna? [in:] I. Jażdżewska (ed.) Człowiek w przestrzeni publicznej miasta. XXIV Konwersatorium wiedzy o mieście, Łódź: Uniwersytet Łódzki, pp. 157-165.

JaRCZEWSKI W., HuCULAK M., 2010. Wpływ rewitalizacji terenów poprzemysłowych na rynek pracy w woj. Ślqskim. Problemy Rozwoju Miast, 4, pp. 34-42.

JLL, 2015. Rynek handlowy w Polsce: 1 kw. 2015. Jones Lang Lasalle IP, INC., http://www.renews. pl/uploads/Raporty/jllhandel12015.pdf [17 June 2015].

Jarosz A., 2002. Miejsce hipermarketów w przestrzeni miejskiej aglomeracji [in:] G. Węcławowicz (ed.), Warszawa, jako przedmiot badań w geografii społeczno-ekonomicznej, Prace Geograficzne, 184, Warszawa: Instytut Geografii i Przestrzennego Zagospodarowania PAN, pp. 253-264.

Kaczmarek T., 2010. Struktura przestrzenna handlu detalicznego. Od skali globalnej do lokalnej. Poznań: Wydawnictwo Naukowe Bogucki.

Kaczmarek T., 2011. Handel detaliczny w rozwoju funkcjonalnym i przestrzennym miast $w$ Polsce [in:] M. Wdowicka, L. Mierzejewska (eds.), Problemy rozwoju lokalnego i regionalnego na początku XXI wieku, Poznań: Biuletyn Instytutu Geografii Społeczno Ekonomicznej i Gospodarki Przestrzennej Uniwersytetu im. Adama Mickiewicza, pp. 67-84.

KACZMAREK T., 2012. Development and spatial structure of retail trade in Poland [in:] P. Churski (ed.), Contemporary Issues in Polish Geography, Poznań: Bogucki Wydawnictwo Naukowe, pp. 157-178.

KŁosIEWICZ-GóreCKA U., 2006. Globalizacja w sektorze handlu w Polsce - wyzwania dla krajowych przedsiębiorstw handlowych [in:] J. Mikołajczyk (ed.), Handel znaczenie we współczesnej gospodarce, Poznań: Wyższa Szkoła Handlu i Usług, pp. 51-68.

KŁosIeWICZ-GóreCKA U., 2009. Zmiany w handlu detalicznym [in:] M. Sławińska (ed.), Handel wewnętrzny w Polsce 1989-2009, Warszawa: Instytut Badań Rynku, Konsumpcji i Koniunktur, pp. 117-143.

KŁosIeWICZ-GóreCKA U., 2010. Zmiany w sieci handlu detalicznego. Wiadomości Statystyczne, 9, Warszawa: Główny Urząd Statystyczny, pp. 36-48.

KŁosieWICZ-GÓRECKA U., SŁomińsKa B., 2001. Samorzad terytorialny, a rozwój nowoczesnego handlu. Warszawa: Difin.

KŁosowsKI F., 2002. Hipermarkety w przestrzeni handlowej miast aglomeracji katowickiej [in:] J. Słodczyk (ed.), Przemiany bazy ekonomicznej i struktury przestrzennej miast, Opole: Uniwersytet Opolski, pp. 373-381.

KneCht-TARCZEWSKA M., 2011. Centrum handlowe jako nowoczesny produkt handlowo-usługowy. Zeszyty Naukowe, 175, Poznań: Uniwersytet Ekonomiczny, pp. 293-303.

KochanieC A., 2011. Rola centrów handlowych w kreowaniu wizerunku miast [in:] A. Grzegorczyk, A. Kochaniec (eds.), Kreowanie wizerunku miasta. Warszawa: Wyższa Szkoła Promocji, pp. 238-247.

Kocluba D., 2006. Nowe przestrzenie handlowe Lublina [in:] I. Jażdżewska (ed.), Nowe przestrzenie w miastach. Ich organizacja i funkcje, XIX Konwersatorium Wiedzy o Mieście, Łódź: Uniwersytet Łódzki, pp. 231-244.

KoHn M., 2004. Brave new neighborhoods. The privatization of public space. New York and London: Routledge. 
KucharSKA B., TwardzIK M., 2007. Koncentracja $i$ integracja $w$ handlu. Aspekt teoretyczny. Dqbrowa Górnicza: Wyższa Szkoła Biznesu.

KWIATKOWSKI K., 2010. Przestrzeń publiczna i jej uzurpatorskie zawłaszczanie. Czasopismo Techniczne. Architektura, vol. 107, no. 2-A, Kraków: Politechnika Krakowska, pp. 277-284.

LeDWoń S., 2009. Przekształcenia obszarów śródmiejskich z udziałem funkcji handlowej [in:] P. Lorens, J. Martyniuk-Pęczek (eds.), Wybrane zagadnienia z rewitalizacji miast, Gdańsk: Urbanista, pp. 36-58.

MakowskI G., 2003. Światynia konsumpcji. Geneza i społeczne znaczenie centrum handlowego. Warszawa: Trio.

MalesZYK E., 1998. Zagraniczne sieci handlowe w Polsce. Gospodarka Narodowa, 8-9, pp. 31-44.

MaLEsZYK E., 1999. Rozwój hipermarketów, supermarketów i sklepów dyskontowych z kapitałem zagranicznym. Wiadomości Statystyczne, vol. 44, no 6, Warszawa: Główny Urząd Statystyczny, pp. 44-52.

MaleszYK E., 2000. Ośrodki handlowe w Polsce. Gospodarka Narodowa, 11-12, pp. 71-85.

MaleszYK E., 2001. Ośrodki handlowe w Polsce uwarunkowania i kierunki rozwoju. Rynek i konsumpcja. Raporty z badań - rok 2000. Warszawa: Instytut Rynku Wewnętrznego i Konsumpcji, pp. 103-114.

MaleszYk E., 2004. Rozwój sieci handlowych obsługi masowej w Polsce. Wiadomości Statystyczne, vol. 49, no. 1, Warszawa: Główny Urząd Statystyczny, pp. 38-49.

Maleszrk E., 2009. Procesy koncentracji i integracji w handlu detalicznym [in:] U. Kłosiewicz-Górecka (ed.), Handel wewnętrzny w Polsce 1989-2009, Warszawa: Instytut Badań Rynku, Konsumpcji i Koniunktur, pp. 144-157.

Maleszyk E., 2011. Nowe trendy w procesach koncentracji i integracji handlu w Polsce [in:] M. Sławińska (eds.), Handel we współczesnej gospodarce. Źródła i przejawy innowacyjności, Zeszyty Naukowe, 175, Poznań: Uniwersytet Ekonomiczny, pp. 40-51.

MiKOtAICZYK J., 2008. Przestrzenne aspekty funkcjonowania handlu [in:] M. Sławińska (ed.), Kompendium wiedzy o handlu, Warszawa: Państwowe Wydawnictwo Naukowe, pp. 288-299.

Mironowicz I., 2010. Wspótczesne dylematy przestrzeni publicznej [in:] P. Lorens,
J. Martyniuk-Pęczek (eds.), Problemy kształtowania przestrzeni publicznych. Miasto. Metropolia. Region, Gdańsk: Urbanista, pp. 36-49.

MordWA S., 2012. Poczucie bezpieczeństwa w centrach handlowych. Przykład badań opinii klientów Galerii Łódzkiej i Manufaktury w Łodzi. Acta Universitatis Lodziensis. Folia Geographica SocioOeconomica, no. 12, Łódź: Uniwersytet Łódzki, pp. 163-187.

NamYŚLAK B., 2006. Rozwój wielkopowierzchniowych obiektów handlowych we Wrocławiu [in:] I. Jażdżewska (ed.), Nowe przestrzenie w mieście, ich organizacja i funkcje, XVIII Konwersatorium Wiedzy o Mieście, Łódź: Uniwersytet Łódzki, pp. 265-276.

PANCEWICZ Ł., 2010. Prywatyzacja przestrzeni publicznych. [in:] P. Lorens, J. Martyniuk-Pęczek (eds.) Problemy kształtowania przestrzeni publicznych. Miasto. Metropolia. Region, Gdańsk: Urbanista, pp. 80-91.

Pilarczyk B., Stawińska M., Mruk H., 2001. Strategie marketingowe przedsiębiorstw handlowych. Warszawa: Państwowe Wydawnictwo Ekonomiczne.

Pokorska B., MaleszyK E., 2002. Koncentracja i integracja na rynku wewnętrznym w optyce sieci handlowych - koncepcja badań [in:] B. Pokorska, E. Maleszyk (eds.), Koncentracja i integracja w handlu wewnętrznym, Warszawa: Państwowe Wydawnictwo Ekonomiczne, pp. 13-26.

Pokorska B., Maleszrk E., 2006. Integracja przedsiębiorstw a procesy konkurencji. Warszawa: Państwowe Wydawnictwo Ekonomiczne.

PRCH - Polska Rada Centrów Handlowych, http://prch.org.pl/ [17 June 2015].

Racoń-Leja K., 2007. Przestrzeń publiczna zagrożona. Czasopismo Techniczne. Architektura, vol. 104, no. 2-A, pp. 215-220.

RAPORT - RYNEK POWIERZCHNI HANDLOWYCH, 2012. Retail market overview in Poland: Report compiled by Cushman \& Wakefield, Warszawa: Cushman \& Wakefield, http://cdn 11.muratorplus.smcloud. net/t/myfile/Rynek-powierzchni-handlowych-w-Polsce_raport-Cushman.pdf [17 June 2015].

RochmińsKA A., 2005. Rozwój sieci handlowych z udziałem kapitału zagranicznego [in:] J. Dzieciuchowicz (ed.), Usługi rynkowe w dobie transformacji, Łódź: Uniwersytet Łódzki, pp. 65-92.

RochminSKA A., 2010. Sieci handlowe z kapitałem zagranicznym jako nowy element $w$ strukturze 
miasta [in:] I. Jażdżewska (ed.), Duże i średnie miasta polskie w okresie transformacji. XXII Konwersatorium Wiedzy o Mieście, Łódź: Uniwersytet Łódzki, pp. 161-172.

RoCHMIŃSKA A., 2011. Zakupy a czas wolny Łodzian. Acta Universitatis Lodziensis. Folia Oeconomica, 11, Łódź: Uniwersytet Łódzki, pp. 207-217.

RochmińsKA A., 2013. Atrakcyjność łódzkich centrów handlowych oraz zachowania nabywcze i przestrzenne ich klientów. Łódź: Uniwersytet Łódzki.

RochmińSKA A., 2014. Centra handlowe jako przestrzenie hybrydowe [in:] E. Klima (ed.), Ludność, mieszkalnictwo, usługi - w 70. rocznicę profesora Jerzego Dzieciuchowicza, Space-Society-Economy, 13, Łódź: Uniwersytet Łódzki, pp. 281-297.

RoCHMIŃSKA A., 2015. Centra handlowe - kreatorzy nowych przestrzeni miejskich [in:] A. Wolaniuk (ed.), Współczesne czynniki i bariery rozwoju miast: XXVIII Konwersatorium Wiedzy o Mieście, Łódź: Uniwersytet Łódzki, pp. 229-246.

SIEMIENIAKO D., 2009. Rozwój centrów handlowych a wzrost atrakcyjności miast [in:] S. Lachiewicz, M. Matejun (eds.), Konkurencyjność jako determinanta rozwoju przedsiębiorstwa. Monografie Politechniki Łódzkiej, Łódź: Politechnika Łódzka, pp. 371-379.

StaWIŃSKA M., 2008. Handel we wspótczesnej gospodarce [in:] M. Sławińska (ed.), Kompendium wiedzy o handlu, Warszawa: Państwowe Wydawnictwo Naukowe, pp. 11-31.

Sobala-Gwosdz A., Gwosdz K., 2011. Polska Wschodnia w strategiach lokalizacji sieci hipermarketów [in:] M. Woźniak (ed.), Uwarunkowania sprawnego działania w przedsiębiorstwie i regionie, Nierówności Społeczne a Wzrost Gospodarczy, 20, Rzeszów: Uniwersytet Rzeszowski, pp. 276-290.

SzULCE H., 1998. Struktury i strategie w handlu. Warszawa: Państwowe Wydawnictwo Ekonomiczne.

SZUMILAK J., 2004. Miejsce i rola handlu detalicznego w procesie gospodarowania [in:] J. Szumilak (ed.), Handel detaliczny funkcjonowanie i kierunki rozwoju, Kraków: Oficyna Ekonomiczna, pp. 11-46.

TAYLOR Z., 2000. Przekształcenia sieci handlu detalicznego i gastronomii w okresie transformacji społeczno-gospodarczej Polski. Prace Geograficzne, 175, Warszawa-Wrocław: Instytut Geografii i Przestrzennego Zagospodarowania PAN, Continuo.
TYNDAll A., 2010. It's a public, I reckon: Publicness and a suburban shopping mall in Sydney's Southwest. Geographical Research, vol. 48, no. 2, pp. 123-136.

WERWICKI A., 2000. Handel targowiskowy aglomeracji łódzkiej na tle jego znaczenia ogólnopolskiego w latach 1994-1997. Szlakami Nauki, 31, Łódź: Łódzkie Towarzystwo Naukowe.

WerWICKI A., 2001. Targowiska [in:] S. Liszewski (ed.), Funkcja regionalna Łodzi i jej rola w kształtowaniu województwa. Zarys monografii województwa łódzkiego. Łódź: Łódzkie Towarzystwo Naukowe, pp. 360-368.

WIĘCŁAW J., 2000. Nowe centra handlowe w strukturze przestrzenno-funkcjonalnej Krakowa [in:] I. Jażdżewska (ed.), Miasto postsocjalistyczne. Organizacja przestrzeni miejskiej i jej przemiany, XIII Konwersatorium Wiedzy o Mieście, Łódź: Uniwersytet Łódzki, pp. 175-177.

WIĘCŁAW J., 2003. Hipermarkety, jako nowy element w strukturze przestrzennej miast Polski na przykładzie Krakowa [in:] Z. Górka, J. Więcław (eds.), Badania i podróże naukowe krakowskich geografów, Kraków: Polskie Towarzystwo Geograficzne, pp. 137-146.

WięCAAW-MiChnieWSKa J., 2006. Nowe przestrzenie handlowe $w$ aspekcie realizacji zadań samorzadu terytorialnego [in:] I. Jażdżewska (ed.), Nowe przestrzenie w miastach. Ich organizacja i funkcje, XIX Konwersatorium Wiedzy o Mieście, Łódź: Uniwersytet Łódzki, pp. 277-286.

WiLK W., 2003. Między zakupami a rozrywka nowe znaczenie centrum handlowego. Prace i Studia Geograficzne, 32, pp. 205-224.

WILK W., 2004. Zachodnioeuropejskie sieci handlowe w Czechach, w Polsce i na Stowacji: Podobieństwa i różnice [in:] E. Jakubowicz, A. Raczyk (eds.), Regionalny wymiar integracji europejskiej, Przekształcania Regionalnych Struktur Funkcjonalno-Przestrzennych, VIII/ 2, Wrocław: Uniwersytet Wrocławski, pp. 231-240.

WILK W., 2005. Miejsce miast $w$ sieciach handlowych - przykład Polski [in:] A. Lisowski (ed.), Zmiany przestrzenne i funkcjonalne obszarów miejskich, Prace i Studia Geograficzne, 35, Warszawa: Uniwersytet Warszawski, pp. 129-153.

WinIARCZYK-RaźnIAK A., 2007. Kompleksowe zaopatrzenie w usługi w regionie miejskim Krakowa (na przykładzie wybranych centrów handlowych) [in:] P. Brezdeń, S. Grykień (eds.), Od lokalnego do globalnego wymiaru gospodarowania przestrzeniq 
- nowe jakości przestrzeni społeczno-ekonomicznej, Przekształcenia Regionalnych Struktur Funkcjonalno-Przestrzennych, Wrocław: Uniwersytet Wrocławski, pp. 351-357.

Wóscık M., 2009. Centrum handlowo-rozrywkowe jako "miejsce” w przestrzeni społecznej Łodzi. Przykład "Manufaktury" [in:] E. Klima (ed.), Czynniki społeczne w gospodarce przestrzennej i planowaniu przestrzennym, Space-Society-Economy, 9, Łódź: Uniwersytet Łódzki, pp. 133-142.

ZIPSER W., 2006, Usługi wielkopowierzchniowe a zachowania przestrzenne mieszkańców dużych miast (na podstawie wrocławskich obserwacji) [in:] J. Słodczyk, R. Klimek (eds.), Przemiany przestrzeni miast i stref podmiejskich, Opole: Uniwersytet Opolski, pp. 63-79. 